\title{
PALYNOLOGIC AND LITHOSTRATIGRAPHIC RESEARCH OF LACUSTRINE, MARSH AND FLUVIAL QUATERNARY DEPOSITS IN RAŠICA DOLINA AND MIŠJA DOLINA, AND ON RADENSKO POLJE
}

\author{
Metka CULIBERG* \& STEVO DOZET**
}

\begin{abstract}
The article deals with the results of palynological and stratigraphical research of lacustrine, marsh and fluvial Quaternary deposits in the Rašica dolina and Mišja dolina, and on Radensko polje. Correlation with equivalent Quaternary deposits and their palynoflora from the Grosuplje polje area was also performed. In the study area, Mesozoic, predominantly carbonate rocks are transgressively covered by Quaternary deposits which are in general composed of five lithostratigraphic units (from bottom to top): 1. gravel, 2. grey lacustrine clay, 3. reddish brown loam, 4. light grey marly clay and 5. alluvial marsh deposits. On the basis of pollen analysis the Quaternary sediments of the study area are chronostratigraphically classified to the Late or Middle Pleistocene and Holocene.

Key words: Central Slovenia, Quaternary deposits, Rašica dolina and Mišja dolina, Radensko polje, lithostratigraphy, palynology, correlation.

Izvleček

Članek podaja rezultate palinoloških in stratigrafskih raziskav kvartarnih jezerskih, barjanskih in fluvialnih usedlin v Rašiški in Mišji dolini ter na Radenskem polju. Narejena je tudi primerjava z ekvivalentnimi sedimenti in palinofloro Grosupeljskega polja. Na obravnavanem ozemlju mezozojske, pretežno karbonatne kamnine transgresivno prekrivajo kvartarne plasti, ki jih na splošno sestavlja pet litostratigrafskih enot (od spodaj navzgor): 1. prod, 2. siva jezerska glina, 3. rdeče rjava ilovica, 4. svetlo siva karbonatna glina in 5. aluvialno močvirske usedline. Na podlagi pelodne analize kvartarne sedimente kronostratigrafsko uvrščamo v mlajši ali srednji pleistocen ter holocen.

Ključne besede: osrednja Slovenija, kvartarne usedline, Rašiška in Mišja dolina, Radensko polje, litostratigrafija, palinologija, primerjava.
\end{abstract}

\section{INTRODUCTION}

In the region of the Pliocene Rašica river basin, that is, in the area of the present streams of Robarica, Kovparica, Rašica, Bičje, Podlomščica, Grosupeljščica, Brvac, Gatinski potok, Zelenka and Dobravka, pedological, biological, geological and palynological studies in recent decades have contributed to better knowledge of the terrain covered by Pliocene and Quaternary deposits.
The scope of the present study is to research the litostratigraphy and examine the palynoflora of the Quaternary deposits in the Rašica dolina and Mišja dolina as well as on Radensko polje, and to correlate them with Quaternary sediments in the Grosuplje polje area (Dozet \& Culiberg, 2005). Due to the scarce fossil content, palaeontological methods were not worth considering. Useful results have been obtained to date only by pollen analysis.

\footnotetext{
* Jovan Hadži Institute of Biology, Scientific Research Centre of the Slovenian Acadamy of Sciences and Arts, Novi $\operatorname{trg}$ 2, SI-1000 Ljubljana.

** Geological Survey of Slovenia, Dimičeva 14, Sl-1000 Ljubljana.
} 


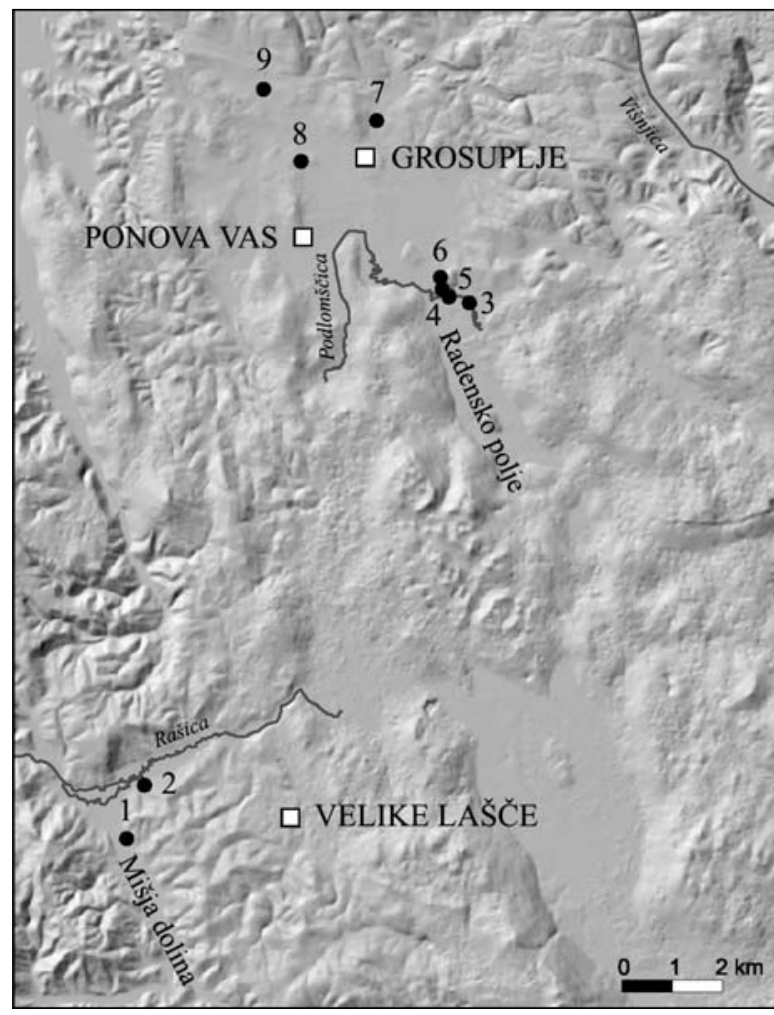

Figure 1: Geographic position of the researched area. Cross sections: 1. Logarji, 2. Stope, 3. Veliko retje, 4. Dobravka, 5. Zagradec, 6. Boštanj, 7. Grosupeljščica river-bed, 8. Brezje and 9. Cikava.

Slika 1: Območje raziskav z lokalitetami: 1. Logarji, 2. Stope, 3. Veliko retje, 4. breg struge Dobravke, 5. Zagradec, 6. Boštanj, 7. struga Grosupeljščice, 8. Brezje in 9. Cikava.

("Vir DMV 12,5, 2005@Geodetska uprava Republike Slovenije").

Geographical setting. The study area lies about $35 \mathrm{~km}$ southeast of Ljubljana. The $4 \mathrm{~km}$ long Rašica valley comprises the flat area extending along both sides of the Rašica river in a southwest-northeast direction. Towards the southeast, the Rašica valley passes into Mišja dolina which is a narrow valley extending $5 \mathrm{~km}$ in a northwest-southeast direction along the streams of Kovparica in the south and Robarica in the north.

Lying between the hills of Molnik (582 m) and Kucelj $(748 \mathrm{~m})$ to the north, the Turjak area to the south and comprising an area of about 14 $\mathrm{km}^{2}$, Grosuplje polje is actually a composed border plain, a flat gently undulating area, with few irregularities (hills, valleys) and a more or less expressive margin. It developed to the south of the contact between water-tight and karstic rocks. There are four isolated solid rock hillocks (Brinjski hrib 409 m, Ježa $391 \mathrm{~m}$, Gorica $380 \mathrm{~m}$ and hillock at Malo
Mlačevo $352 \mathrm{~m}$ ) in the Grosuplje depression, giving it the feeling of an undeveloped karstic topography. According to Melik (1955, 1959), Grosuplje polje is a young closed depression, typical of karst topography, originating in the area of the Pliocene Rašica river basin. In view of its main characteristics, it is a fairly undeveloped interior valley, or a young polje.

Radensko polje is the southeastern prolongation of Grosuplje polje. Measuring about $4 \mathrm{~km}^{2}$, it is one of the smallest karstic depressions with a flat floor in Slovenia. Moreover, in Melik's opinion (1955, 1959), Radensko polje has all the characteristics of a typical karstic interior valley. Since it opens towards the northwest, Meze (1977) suggested that it would make sense to classify Radensko polje as an individual polje, with the annotation "opened karstic polje".

Geological setting. This study actually covers four depressed depositional areas. Mišja dolina depression was produced by erosion along the NW-SE Mišja dolina fault, while the Rašica valley depression was formed by erosional activity along the SW-NE Rašica fault. The carbonate floor of the Rašica depressed area is covered by Quaternary deposits, but its surrounding consists of Triassic rocks. Red loams predominate among the Upper Pliocene sediments, while lacustrine sediments are most often clay and among the alluvial deposits contain silt, sand, clay and various types of soil.

Grosuplje polje is the largest flat area, originating at the point of intersection of the NW-SE, N-S and NE-SW fault systems. NW-SE faults predominate. The greater part of the area is covered by Late Pliocene and Quaternary deposits. The solid rock basis of the Grosuplje polje consists of Upper Triassic "Hauptdolomit", and its surroundings of Mesozoic, prevalently carbonate rocks. The isolated hills in the Grosuplje polje are composed of Upper Triassic dolomite (Hauptdolomit), Upper Triassic limestone ("Dachsteinkalk") and Lower Jurassic limestone.

Radensko polje, the southeastern prolongation of Grosuplje polje was produced by erosion along the Dinaric Čušperk fault.

Hydrogeography. In spite of the karst topography and, in some places, typical karst phenomena (karst springs, sinkholes, estavelles, swallow holes and subsurface waters) the hydrographic network of the study area is relatively well-developed. In the non-typical karst areas, the Rašica, Grosupeljščica, Dobravka, Podlomščica and some other streams have a permanent flow of water. On the basis of 
some dry valleys, Melik $(1955,1959)$ proved that in the Pliocene, the Rašica river flowed towards Šmarje and Ljubljana Barje. On the other hand, it has been proved by colouring the water that the actual Rašica stream flows towards Dobro polje and the Krka river. However, the regular Grosuplješčica surface water network is developed in the Grosuplje depression. The Grosupeljščica stream flows from Grosuplje polje down to Radensko polje carrying the water further through the karst interior to the Krka river.

The hydrography of Radensko polje has a typical karst character. Clayey alluvial plains determined shallow brook channels with meanders, and frequent inundations in early spring and late autumn, although they can occur at any season (Meze 1977, Meze et al. 1981).

Previous investigations. The part of Slovenia under consideration was first mapped by Lipold (1858). The result of the mapping was a manuscript geological map Višnja gora - Cerknica 1:75 000 (Lipold \& Stache 1859). Kossmat's (1905, 1906) tectonic, structural and stratigraphic studies are important. In Žurga's opinion (1938), a major part of Dolenjsko loam was brought from its former site by natural agents. Hrovat (1953) described the characteristics of karstic loams and their influence on buildings. The author advocated the theory of insoluble remains, or a residual origin. Melik $(1955,1959)$ studied the hydrographic evolution and geomorphology of Slovenian karstic plains during strong climatic changes in the Pleistocene epoch. On the basis of collected data, Rakovec $(1956 \mathrm{a}, \mathrm{b})$ compared different parts of Slovenia in the Pleistocene epoch and made a short survey of the tectonic structure of Slovenia. Tancik (1959) described the pedologic characteristics of the Ribnica and Kočevje valleys. Kerčmar (1961) geologically mapped the vicinity of Taborska jama by Grosuplje. By pollen analyses of sediments from Ljubljana Barje and also from Grosuplje polje, Sercelj $(1962,1966,1970)$ investigated the Quaternary vegetation and climate of Slovenia. Sifrer (1967) described the Quaternary development of the Rašica and Dobro polje valleys. A geological map of the map sheet for Ribnica, with an explanatory text, has been printed within the framework of systematic regional geological mapping for the Basic Geological Map of Slovenia 1:100 000 (Buser, 1969, 1974). Gregorič (1969) studied the connection between carbonate rocks and red soils. In her opinion, the red brown soil developed from insoluble remains of carbonate rocks. She also demon- strated that the loam between Škofljica and Šmarje is autochthonous fossil soil. She also believed that the loam in Dolenjska and Bela Krajina is partly alluvial. Radinja et al. (1974) studied the geography of the flood area in Slovenia. A contribution to the hydrology of the Radensko polje was written by Meze (1977). Meze et al. (1981) studied flood areas in the Grosuplje polje. The formation of the Kočevje-Ribnica loam was described and subdivided by Dozet (1982). The age and stratigraphic position of this and two other formations were discussed by Šercelj \& Dozet (1982). The red Dolenjska loams and geologic structure of the area to the north of the line Šmarje-Sap-Grosuplje were researched by Dozet (1985). Dozet \& Culiberg (2005) recently researched the lithostratigraphy and pollen content of deposits in the Grosuplje polje area.

\section{METHODS}

The results presented in the paper were obtained within the frame of systematic regional geological investigations for the Geological Map of Slovenia 1:50 000. The geological mapping is carrying out on topographic maps on the scale of 1:5000 and 1:10 000. The principal mapping methods are the method of all outcrops and stratimetric profiling. The carbonate rocks are classified according to Folk's (1959) and Dunham's (1962) classification, while for clastic sediments, Folk's (1959) and Pettijohn's (1975) classification have been used. A few samples from each of the investigated sediment profiles were taken for pollen analysis. They were prepared using standard laboratory procedures after Faegri \& Iversen (1992). Due to the scarce pollen content, the results are presented in tables by numerical values of pollen grains.

\section{RESULTS}

\subsection{Results of stratigraphic and palynologic studies}

Within the framework of the elaboration of the Geological Map of Slovenia, Map Sheet Grosuplje 1:50 000, we continued geological mapping and palynologic examination of Quaternary and Plio-Quaternary sediments in the Grosuplje and Radensko polje depressed area, as well as in the alluvial plains along the Rašica river (Veliki log) and its tributaries the Robarica and Kovparica (Mišja 
dolina). Depressions in the Rašica river basin are similar to flood areas in the Grosuplje polje covered by Quaternary deposits. They were stratigraphically and palynologically investigated in the following cross sections:

\subsubsection{Mišja dolina}

Cross-section: fishpond at Logarji. The Quaternary sediments in Mišja dolina are most exposed in the area of the fishpond at Logarji. The sedimentary succession consists of five lithostratigraphic units:

- The basal unit is $2-3 \mathrm{~m}$, at the edges up to 5 $\mathrm{m}$ or more, thick layer of moderately thick and moderately rounded poorly-spheric carbonate gravel. It is a result of Pleistocene fluvial accumulation.

- The carbonate gravel is overlain by a $3.5 \mathrm{~m}$ thick horizon, in lower $1 \mathrm{~m}$ composed of a dark grey to grayish black clay and in the upper $2.5 \mathrm{~m}$ of bluish grey clay.

- The subsequent layer upwards is 1 to $1.5 \mathrm{~m}$ thick yellow orange loam, which is a fluvial sediment, since it contains round grains formed by transport.

- The Holocene part of the Quaternary depositional sequence begins with light grey clay with charred plant remains.

- The uppermost lithostratigraphic unit consists in the lower part of dark grey to black more or less clayey marshy alluvial deposits composed of clay, silt and fine sand.

\section{Pollen analyses}

In $8 \mathrm{~m}$ deep profile from Mišja dolina clay layers in the second and fourth stratigraphic units were investigated palynologically, the upper layer is recent, a Holocene sandy-clayey layer with plant remains, and is chronostratigraphically irrelevent for the purpose of this paper.

As regards to the results of pollen analyses it is clear that the series of different clay sediments investigated was deposited in the cold Pleistocene period, since pollen of cold period vegetation completely predominated in all five samples - pollen of conifers, pine (Pinus) and spruce (Picea), to a lesser extent also birch (Betula). In addition, spores of the arcto-alpine fern, lesser clubmoss (Selaginella selaginoides), appear. Of deciduous trees, hazel (Corylus) and alder (Alnus) are best represented, but these are more ecological than climatic indicators. Individual pollen of birch (Ulmus) and oak (Quercus) can be carried from a distance by air transport or sediments from warmer phases can be re-deposited or, perhaps the two species survived at that time as individual trees or shrubs in favourable niches. More indicative are the unusually high values of lime (Tilia). Similarly high values of lime pollen are known from a profile between the settlements of Selca and Dolenja vas in the valley of Selška Sora (Culiberg 1991), but these layers are not comparable in temporal terms because they are postglacial (C14 $9150 \pm 200 \mathrm{BP})$. These in Mišja dolina are probably older.

The pollen in sample 2, and especially in sample 3 shows that Betula was unusually strongly spread. This may be a result of fires, as the charred plant remains indicate. Birch is known to have the capacity easily and quickly to settle on areas that have burned and thus temporarily overtake all competitors, which grow more slowly. This also applies to some extent to hazel in "open vegetation «.

As concerns herb vegetation, it is necessary to stress in particular the characteristic lesser club-

Table 1: Pollen analysis of sediments from Mišja dolina. Cross-section fishpond at Logarji.

Tabela 1: Pelodna analiza vzorcev sedimenta iz profila ribnika pri Logarjih v Mišji dolini.

\begin{tabular}{|c|c|c|c|c|c|c|c|c|c|c|c|c|c|c|c|c|c|c|c|c|c|c|c|c|c|}
\hline 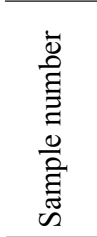 & 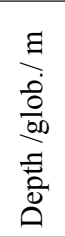 & $\begin{array}{l}\mathfrak{\Xi} \\
\stackrel{\Xi}{\Xi}\end{array}$ & $\underset{\mathscr{8}}{: 0}$ & $\frac{\substack{0 \\
\frac{1}{2}}}{\frac{0}{2}}$ & $\begin{array}{c}\stackrel{\Xi}{\Xi} \\
\stackrel{\Xi}{\Xi} \\
\infty\end{array}$ & $\frac{\mathfrak{\Xi}}{\stackrel{\Xi}{\Xi}}$ & $\frac{3}{3}$ & $\underset{\mathbb{N}}{\stackrel{\Xi}{*}}$ & 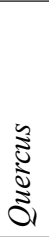 & $\underset{\mathbf{\Xi}}{\stackrel{\Xi}{5}}$ & : & 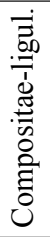 & 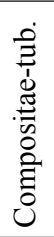 & 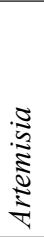 & 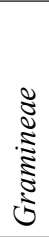 & 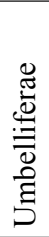 & 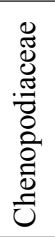 & 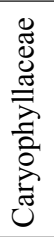 & 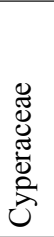 & 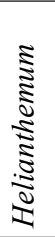 & 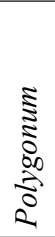 & 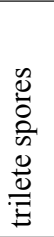 & 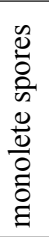 & 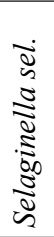 & 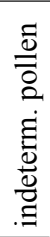 \\
\hline $25883 / 1$ & 0,35 & 194 & 6 & 4 & 12 & 1 & 2 & - & - & - & - & & 8 & 2 & 2 & 1 & 1 & 1 & 65 & - & 4 & 2 & 15 & 6 & 3 \\
\hline $25883 / 2$ & 1 & 137 & 12 & - & 48 & 5 & 15 & 15 & - & - & 3 & 7 & 7 & 4 & 6 & 23 & 2 & 1 & 17 & - & 2 & 5 & 43 & 2 & 17 \\
\hline $25883 / 3$ & 1,75 & 129 & 1 & - & 100 & 2 & 8 & 1 & 1 & 1 & - & 1 & 9 & 1 & 8 & 6 & - & - & 65 & - & - & - & 13 & 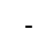 & - \\
\hline $25883 / 4$ & 3,75 & 355 & 5 & 7 & - & - & - & - & - & - & - & 3 & 2 & - & - & 7 & 6 & 2 & 1 & - & - & 3 & - & 3 & - \\
\hline $25883 / 5$ & 5,5 & 218 & 6 & 1 & 1 & - & - & 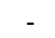 & 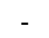 & - & 5 & - & 14 & 6 & 13 & 1 & 2 & 1 & 25 & 1 & 6 & 3 & 53 & 4 & 17 \\
\hline
\end{tabular}


moss (Selaginella selaginoides) and the umbellifer family (Umbelliferae) in sample 2 - immediately after fire. Grasses (Gramineae), as well as wormwood (Artemisia) and goosefoot (Chenopodiaceae), immediately the cold releases, are the first to settle more or less bare sandy and alpine slopes, although they were not particularly successful here. The constant presence of the sedge family (Cyperaceae) and a plant of standing water reedmace (Typha) shows that it was more or less swampy in the valley.

What age can be ascribed to these sediments? There is no doubt that they were deposited in the Pleistocene. Because frigophilous and it could also be said eurythermal forest vegetation predominates, occasionally joined by thermophilous deciduous trees, it can be concluded that extremely cold conditions are not indicated. The stratigraphic position suggests the declining phase of the Würm glaciation, late glacial. However, because of the absence of beech, or at least we have not ascertained the pollen of beech to date here, it is possible that these layers are older than Würm.

\subsubsection{Rašica dolina}

Cross-section: Stope claypit. Stope brick kiln recently operated at the junction of Rašica dolina and Mišja dolina. The clay was dug in the claypit there and in smaller claypits in the Rašica valley. The Quaternary deposits are divided in five lithostratigraphic units:

- 10-7 m: poorly-rounded carbonate gravel.

- 7-3 m: the $4 \mathrm{~m}$ thick layer of clay consists of medium dark grey clay, between dark grey clay below and pale yellowish to moderate grey clay above.

- 3-1 m: grayish orange to reddish loam containing more or less fine sand.
- 1-0.5 m: light grey marly clay.

- 0.5-0 m: alluvial deposits, clay, silt and fine sand respectively.

\section{Pollen analyses}

Of these five sedimentary units in the geological profile, only a second and partially also a third, gave useful palynological results. The deepest unit, weathered carbonate gravel is unsuitable for pollen analysis. The results of pollen analysis are shown in Table 1 in the numerical values of pollen grains and spores found. Some pollen grains in all strata were strongly corroded.

The pollen assemblage of tree vegetation of the lower three strata is characteristic of the Pleistocene cold period. Complete domination of conifers is observable - pine (Pinus) and partially spruce (Picea). Ephedra (Ephedra) is also regularly present. Although the presence of this heliophilous species is unusual for that time, palaeopalinologists often find its pollen in cold period sediments. Birch (Betula), together with pine, was typical pioneer vegetation in some periods of the Pleistocene, mainly at the end of the Würm glacial. In contrast, representatives of thermophilous tree vegetation are very modestly represented. Only a few pollen grains of elm (Ulmus), alder (Alnus) and hazel (Corylus) were found in this sediments.

Of the herb vegetation, wormwood (Artemisia) and the goosefoot family (Chenopodiaceae) are more important. These first settled areas in the periglacial space uncovered from glaciers or permafrost. Grasses (Gramineae) appear in open vegetation of newly created soils. Spores of lesser clubmoss (Selaginella selaginoides), a plant of alpine and tundra grasslands, are particularly indicative. We found other spores of ferns (monolete spores of Dryopteris type and trilete spores of Pterydium type)

Table 2: Pollen analysis of sediments from Rašica dolina. Cross-section Stope claypit.

Tabela 2: Pelodna analiza vzorcev sedimenta iz profila glinokopa Stope v Rašiški dolini.

\begin{tabular}{|c|c|c|c|c|c|c|c|c|c|c|c|c|c|c|c|c|c|c|c|c|c|c|c|c|c|c|c|c|}
\hline 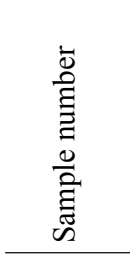 & 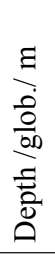 & 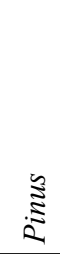 & 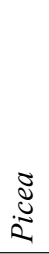 & $\frac{\frac{0}{3}}{\frac{0}{2}}$ & 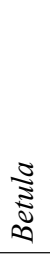 & $\frac{\widehat{\Xi}}{\stackrel{\Xi}{\sharp}}$ & $\frac{\mathfrak{a}}{\stackrel{\Xi}{0}}$ & 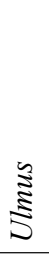 & $\frac{\ddagger}{\tilde{\Xi}}$ & 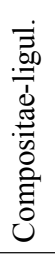 & 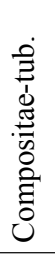 & 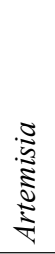 & 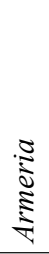 & $\begin{array}{l}\stackrel{\mathscr{J}}{\stackrel{\Xi}{\Xi}} \\
\stackrel{\Xi}{\Xi} \\
\stackrel{\Xi}{\Xi}\end{array}$ & 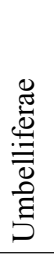 & 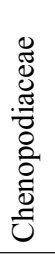 & 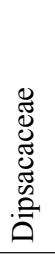 & 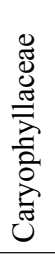 & 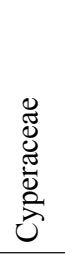 & 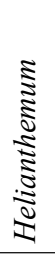 & 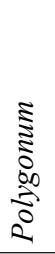 & 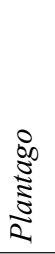 & $\stackrel{\Xi}{\Xi}$ & 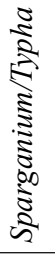 & 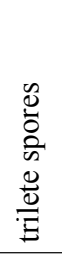 & 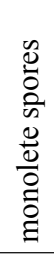 & 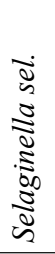 & 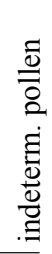 \\
\hline GR28705/4 & 1,5 & - & - & 1 & 1 & 3 & 5 & 2 & - & - & - & - & - & - & - & - & - & - & - & - & - & - & - & 3 & 221 & 161 & 1 & 3 \\
\hline GR28705/3 & 3 & 263 & 9 & 1 & - & 1 & - & - & 2 & - & 10 & 12 & - & 6 & 1 & 3 & 1 & 3 & 23 & 2 & 1 & 1 & 2 & - & 3 & 20 & 4 & 15 \\
\hline GR28705/2 & 5 & 186 & 3 & 5 & 1 & - & 3 & - & 1 & 1 & 1 & 8 & - & - & - & - & - & - & 74 & 2 & 2 & 2 & - & - & 6 & 3 & 6 & 6 \\
\hline GR28705/1 & 6 & 294 & 7 & 7 & 5 & - & 1 & - & - & 3 & 8 & 5 & 2 & 11 & 7 & 2 & - & - & 56 & - & 5 & 1 & - & 1 & 2 & 10 & 16 & 14 \\
\hline
\end{tabular}


in almost all sediments, irrespective of age and climatic conditions.

The upper stratum at a depth $1.5 \mathrm{~m}$ contains only a little, poorly preserved pollen - Corylus and Ulmus. It is characteristic that there is no coniferous pollen here, although this does not mean that there was no pine or spruce. Damper soil conditions are indicated by the large number of fern spores and perhaps also sphagnum moss (Sphagnum). Ephedra and Selaginella selaginoides do not belong in this environment, but their pollen is very robust and resistant and probably came into the layer when the stream eroded the older layer and it lodged here. Torrential streams are known frequently to change course and when they erode their own banks they carry off and deposit older material in younger layers as a redeposit.

The second $(7-3 \mathrm{~m})$ and partially third (3-1 m) stratigraphic units of the profile from Stope claypit must be classified into the Pleistocene in view of the pollen content, with explicitly frigophilous vegetation. However, it is not certain whether this is the Würm or an older cold period. There are few similarities here to conditions in the late glacial. If there was at least some pollen of beech, this would mean a considerable probability that it is the end part of the Würm period, since beech only resettled this area at the end of the Riss-Würm interglacial. Its pollen has also been found in all slightly warmer parts of the Würm.

\subsubsection{Radensko polje}

The solid rock footwall of Quaternary deposits comes to light in numerous places of the Radensko polje area. In the extreme northwestern part of Radensko polje the bedrock of the youngest deposits is grey to light grey "Hauptdolomit". It is characterized by thin laminae and stromatolitic textures, typical Lofer structures and textures. The solid base of the other part of Radensko polje consists of various Lower Jurassic limestones, among which medium grey, grey, and dark grey micrites predominate. Lithiotid limestones occur to a greater extent on the margins of Radensko polje and on Kopanj hillock. In terms of lithological composition and fossils, the paleorelief of the extreme northwestern part of Radensko polje consists of Hauptdolomit. The other part of this polje is composed of Lower and Middle Liassic limestones. However, the formation of the paleorelief of Radensko polje has not yet ended. The immaturity of the paleorelief is shown by the appearance of relatively numerous hillocks and rock cliffs in the Quaternary deposits. The dolomitic paleorelief is coniform, but the limestone one is step-like.

Cross-section: Veliko retje swallow hole. The Quaternary deposits of Radensko polje are most exposed here.

- The bedrock is erosively and discordantly covered by medium light grey to light grey, poorly rounded carbonate gravel. In some places dolomitic pebbles predominate but elsewhere limestone ones are most frequent. The thickness of the layer of basal gravel varies from 2 to $3.5 \mathrm{~m}$, and extremely $5 \mathrm{~m}$. The gravel was washed down from neighbouring hills and by streams crossing the plains in the Pleistocene epoch.

- Upwards follows grey (light, medium, dark) greasy clay, in places containing silt and more or less charred plant remains and organic detritus. The clay was deposited in the still water of a relatively shallow pond, or small lake.

- The grey greasy clay passes upwards into a greenish, yellowish and reddish brown, from 1 to $2.5 \mathrm{~m}$ thick, layer of loam with small lenses and spots of grayish clay. Its mineral composition varies both laterally and vertically. It is, in fact, terra rossa washed off from neighbouring slopes.

- Upwards follows an up to $0.75 \mathrm{~m}$ thick layer of light grey marly clay.

- The layer of dark grey to greyish black acidic soil is of Holocene age. At the surface there is a layer about $0.25 \mathrm{~m}$ thick, of alluvial deposits, clay, silt and fine sand.

\section{Pollen analyses}

On Radensko polje, along the bank of the Dobravka, a borehole was hand drilled to bedrock at a depth of $5.30 \mathrm{~m}$ below the level of the plain. The sediment is throughout grey-brown clay, alluvium of the Dobravka. However, this clay is not pseudogley, a weathered product of secondary oxido-reduction processes, but is primary, unaltered sediment. The pollen preserved in it is certainly evidence of this.

Six samples were subjected to pollen analysis. On the basis of typical palynocenoses of individual samples and horizons, three phases can be distinguished, indicating three chronostratigraphic segments.

Phase $1(5.30-4.40 \mathrm{~m})$ : Domination of pine $(\mathrm{Pi}$ nus) and birch (Betula) and herb vegetation with 
Table 3: Pollen analysis of sediments from the core drilled along the bank of the Dobravka on Radensko polje.

Tabela 3: Pelodna analiza vzorcev sedimenta iz vrtine ob strugi Dobravke na Radenskem polju.

\begin{tabular}{|c|c|c|c|c|c|c|c|c|c|c|c|c|c|c|c|c|c|c|c|c|c|c|c|c|c|c|c|c|c|c|c|}
\hline $\begin{array}{l}\Xi \\
\dot{0} \\
0 \\
000 \\
\frac{1}{0} \\
\frac{0}{0} \\
0 \\
\end{array}$ & 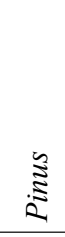 & $\begin{array}{l}\tilde{8} \\
\mathbb{8} \\
2\end{array}$ & 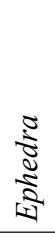 & 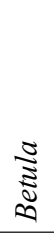 & $\underset{\Xi}{\stackrel{\Xi}{\Xi}}$ & $\frac{3}{3}$ & 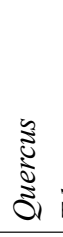 & $\underset{\mathbb{N}}{\stackrel{\Xi}{*}}$ & $\begin{array}{l}3 \\
5 \\
8 \\
0 \\
\end{array}$ & 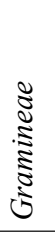 & 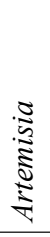 & 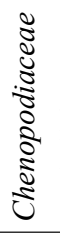 & 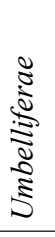 & 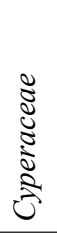 & 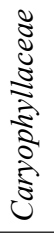 & 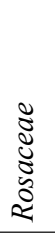 & 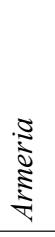 & $\begin{array}{l}\tilde{\Xi} \\
\tilde{\Xi} \\
\stackrel{\Xi}{\Xi} \\
0\end{array}$ & 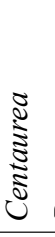 & 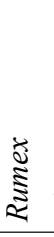 & 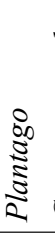 & 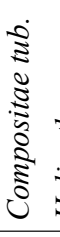 & 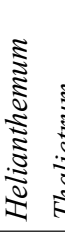 & 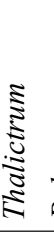 & $\begin{array}{l}\Sigma \\
\vdots \\
0 \\
\infty \\
2 \\
0 \\
2 \\
2\end{array}$ & $\frac{\sqrt{2}}{5}$ & 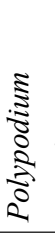 & 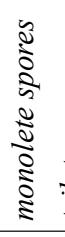 & 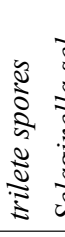 & 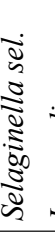 & 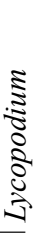 \\
\hline 3 & 15 & 19 & - & 2 & 6 & 5 & - & 4 & 2 & 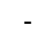 & 1 & 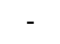 & - & 4 & 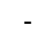 & 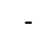 & 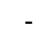 & - & - & 1 & - & 12 & 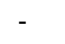 & - & 6 & 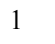 & 2 & 26 & 1 & 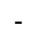 & \\
\hline 3,5 & 4 & - & - & 2 & - & - & - & - & - & - & 1 & - & - & - & - & - & - & - & - & - & - & - & - & - & - & - & 2 & - & - & 1 & 1 \\
\hline 3,95 & 15 & 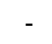 & - & 2 & - & - & - & - & - & 1 & 4 & 5 & - & - & 3 & - & 1 & 1 & - & - & - & 4 & - & . & 1 & & 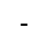 & 1 & 1 & & 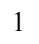 \\
\hline 4,40 & 20 & 1 & - & - & - & 1 & - & - & - & 1 & 10 & 1 & 1 & - & 1 & - & - & 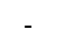 & - & - & - & 6 & 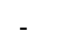 & 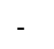 & 1 & . & - & . & - & 1 & 1 \\
\hline 4,90 & 160 & 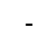 & - & 6 & 1 & - & - & - & - & - & 70 & 26 & 3 & - & - & - & - & - & 1 & - & 1 & 2 & 9 & 1 & 2 & - & - & 1 & - & - & \\
\hline 5,30 & 232 & - & 3 & 25 & 5 & - & 1 & - & - & 7 & 78 & 33 & 5 & _ & 4 & 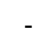 & - & 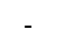 & - & 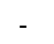 & 5 & 5 & 1 & 1 & 1 & . & - & 1 & & 1 & 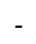 \\
\hline
\end{tabular}

wormwood (Artemisia) and the goosefoot family (Chenopodiceae) indicates a cold period at the end of the Würm. That there was then and prior to that a period of even colder period is also indicated by the spores of lesser clubmoss (Selaginella selaginoides) and partly also the pollen of rockrose (Helianthemum) and the family Compositae.

Phase 2: (3.95-3.5 m): There was little pollen in two samples but still some pollen grains of pine and birch and some herb species. More powerful water flows probably carried off pollen during warmer conditions.

Phase $3(3 \mathrm{~m})$ : There is also little pollen in this part, but it is sufficiently characteristic for us to conclude that it is Holocene. There were already lime (Tilia), beech (Fagus) and hazel (Corylus) here. Judging from the pollen coenosis, this sedimentary complex is relatively young, which is also confirmed by the good state of preservation of the sediment itself.

Slightly lower than the water current, immediately below the village of Zagradec, another 105 $\mathrm{cm}$ deep borehole was drilled. The sediment there was dark grey, greasy clay, deposited in standing or calm water. Two samples were analysed for pollen. In the lower sample $(105 \mathrm{~cm})$ there was a considerable amount of pollen: of tree species almost exclusively pine (Pinus) and only single grains of spruce (Picea), birch (Betula) and hazel (Corylus). The pollen content of herbaceous pollen is modest but a wide range of species. There are also spores of lesser clubmoss (Selaginella selaginoides) which, together with pine, signify a cold period, the end of the last glacial.
In the upper sample, too, from a depth of 30 $\mathrm{cm}$, tree vegetation is only represented by pine $(P i$ $n u s$ ), and herb vegetation by wormwood (Artemisia), the goosefoot family (Chenopodiaceae) and rockrose (Helianthemum).

\subsubsection{Grosuplje polje}

In order to compare the Quaternary sediments of Rašica dolina, Mišja dolina and Radensko polje depressions with the sediments of Grosuplje depression some most prominant and most characteristic cross-sections of the Quaternary stratigraphic sequences are represented:

Brezje cross-section. The solid rock of the Quaternary stratigraphic sequence is represented by black, greyish black, dark grey and grey, finely laminated Upper Triassic dolomite dipping towards the south and belonging to the Hauptdolomit formation. The contact between the Hauptdolomit and Quaternary deposits is at the depth of $7.5 \mathrm{~m}$ (Dozet \& Culiberg, 2005).

- 7.5-5.5 m: greenish grey greasy clay passes upwards into the dark grey clay and the grey clay at the top; the latter may passes laterally into micaceous silt. The dark grey clay contains organic remains.

- 5.5-4 m: grey to medium dark grey, more or less silty clay passes in spots laterally into micaceous silt.

- 4-2 m: greenish and yellowish brown, yellowish orange to orange loam.

- 2-1.5 m: light grey marly clay with plant remains. 
- 1.25-0.5 m: greyish black and black marly clay rich in plant remains.

- $0.5 \mathrm{~m}$ to $0 \mathrm{~m}$ : dark grey to grayish black marshy alluvial soil. Occasionally, small fragments of carbonate rocks deposited horizontally as thin intercalations in the soil, creating a stratification point of fluvial (alluvial) origin.

Boštanj cross-section. The brickworks still operated until recently exploiting the light grey clay from the claypit south of Boštanj castle. The bedrock consists of stratified Hauptdolomit. The contact with the Quaternary deposits is not exposed. The lithostratigraphic structure of the profile is as follows:

- The Quaternary stratigraphic sequence starts with lacustrine clay. The clay horizon is about $5 \mathrm{~m}$ thick. The clay is of various grey colours, of various composition and quality. The light grey clay has the best quality. There are some thin intercalations of silt and yellowish very finegrained quartz sand in the clay horizon.

- From 2-1 m: in the lower part reddish brown and in the upper part greenish and yellowish brown more or less sandy loam occurs.

- From 1-0 m: more or less humic, acidic and clayey soils.

Cikava cross section. Quaternary sediments from the bottom of the brook at Cikava near Grosuplje were palynologically examined by Šercelj (1970). Elements of arctic flora with Selaginella selaginoides and Pinus sp. were found in the yellow clay which, in the author's opinion, is reduced terra rossa from the neighbouring slopes.

Frigoriphilous vegetation but richer in species has also been established in samples from another two short sedimentary cores from a site east of Grosuplje (Šercelj 1970). According to the author, these pollen record probably represent würmian vegetation but the one at Cikava could be still older.

Cross-section Grosupeljščica river-bed. In 3 to $4 \mathrm{~m}$ deep Grosupeljščica river-bed there is exposed a cross-section of the Pleistocene (gravel) and of the Holocene deposits consisting of the following layers:

- At the bottom of the river-bed, there is exposed $0.75 \mathrm{~m}$ thick layer of poorly-sorted and poorlyrounded, fine- to medium-grained mixed carbonate-silicious gravel from the Permo-Carboniferous clastic rocks as well as the Upper Triassic and Lower Jurassic dolomites and limestones. According to the stratigraphic position and the composition of the gravel and with reference to analogy with other cross-sections of the Quaternary deposits in the Grosuplje depression, we are of the opinion, that it is the basal Pleistocene sedimentary unit.

- The Pleistocene gravel is overlain by $0.25 \mathrm{~m}$ thick layer of the grey sandy clay with organic remains and larger pieces of wood. In two samples Holocene vegetation was ascertained by pollen analysis (Šercelj: in Meze et al. 1981).

- Over the grey sandy clay lies a $0.25 \mathrm{~m}$ thick layer of gravel of the same composition as the basal gravel, to which Pleistocene age is attributed. According to the Holocene vegetation in the lower grey sandy clay this gravel horizon belongs to the Holocene.

- Upwards there is a sharp boundary between the early Holocene gravel and the overlying 0.50 $\mathrm{m}$ thick horizon of stratified, more or less finegrained sediment, in which fine gravel, sand and silt alternate.

- The upper $1.50 \mathrm{~m}$ thick layer of yellowish grey sandy loam includes occasional dolomite, limestone, sandstone and quartz sandstone pebbles belonging to Permo-Carboniferous, Triassic and Jurassic rocks. The pollen record in the sample from this layer (Sercelj: in Meze at al. 1981) indicates a prehistoric time at the beginning of agriculture.

\section{DISCUSSION AND COMPARISION OF QUATERNARY DEPOSITS, EVENTS AND POLLEN CONTENT IN RAŠICA DOLINA AND MIŠJA DOLINA, RADENSKO AND GROSUPLJE POLJE}

Comparing the Quaternary deposits of the considered four depressions, we came to the conclusion that there are several important similarities.

1. The collected data show that Rašica dolina and Mišja dolina originated in the Late Pliocene. On the other hand, with a much more immature paleorelief the Grosuplje and Radensko polje depressions must be somewhat younger.

2. Comparing all described Quaternary lithological columns, it can be seen that the basal Quaternary sediment, or gravel, is absent in the 
Grosuplje polje. Since the oldest pebble filling is not present, two explanations are possible:

- There was no sedimentation in the Grosuplje polje in the Early Pleistocene epoch.

- The pebble filling in the Rašica dolina took place simultaneously with the lower part of the grey greasy clay in other places.

3. All other Quaternary beds are mutually comparable. In the Pleistocene epoch, grey greasy clay, overlain by brown clays of fluvial origin, was formed in the area of all the described depressions.

4. According to present data, the Holocene begins in all depressions with light grey marly clay overlain by alluvial-marshy acidic deposits. The light grey marly clay is presumed to be an equivalent of the Ljubljana Barje marly clay ("polžarica").

5. The thickness of Quaternary deposits in the area of the considered depressions is approximately equal, varying in the range of 7.5 to $10 \mathrm{~m}$.

\section{CONCLUSIONS}

Stratigraphical and palynological research of Quaternary deposits in Rašica dolina and Mišja dolina and in Radensko and Grosuplje polje depressions provided an insight into the geological structure, age, lithological composition and inter-relationships of Pleistocene and Holocene lithostratigraphic units, as well as their relationship to older Upper Pliocene, Triassic and Lower Jurassic sedimentary rocks.

On the basis of a synthesis of the collected geological data of geological mapping and the results of palynological analysis, we came to the following conclusions:

- Neotectonic faulting, a warmer climate, karstification, and various weathering processes and erosion in the Upper Pliocene led to the creation of a fairly expressive paleorelief and a cover of red bauxitic clays a few metres thick.

- In the Pleistocene, the study area sank along the fault systems of various directions (NW-SE, N-E, NE-SW), whereupon an erosion and occasional filling with carbonate gravel occurred. The climate cooled down. Small shallow lakes were formed, in which clays, silts and fine sands were deposited. When the lakes began to drain, a marshy environment originated.

- The Quaternary deposits in the study area are poor in fossils and pollen.

- The thickness of the Quaternary deposits in the considered area is fairly constant, ranging from 7.5 to 10 metres.

\section{ACKNOWLEDGEMENTS}

The authors are much obliged to the Ministry of Education, Science and Sport of the Republic of Slovenia as well as to the Geological Survey of Slovenia and Jovan Hadži Institute of Biology, Scientific Research Centre of the Slovenian Academy of Sciences and Arts, which enabled our investigations in the field and laboratory.

\section{POVZETEK}

Palinološke in litostratigrafske raziskave jezerskih, barjanskih in fluvialnih kvartarnih usedlin Rašiške in Mišje doline ter Radenskega polja

Stratigrafske in palinološke raziskave kvartarnih usedlin Rašiške in Mišje doline ter Radenskega polja so dale vpogled v geološko zgradbo, sestavo, nastanek, starost, paleogeografske razmere in superpozicijske odnose pleistocenskih in holocenskih usedlin ter njihov odnos do starejših t.j. zgornjepliocenskih, triasnih in spodnjejurskih kamnin.

Neotektonski premiki, toplejša klima in močno preperevanje so v mlajšem pliocenu privedli zlasti na območju Grosupeljske kotline do nastanka dokaj razčlenjenega paleoreliefa in nekaj metrov debelega prekritja z rdečimi boksitnimi ilovicami. $\mathrm{Na}$ prehodu iz pliocena $v$ pleistocen so se posamezni deli ozemlja ob različnih prelomnih sistemih vertikalo premaknili. Prišlo je do erozije ter nastanka večjih in manjših depresij. Sledilo je zasipavanje novonastalih kotanj s karbonatnim, v manjši meri tudi z drugačnim prodom. Narasle vode so poleg kamninskega drobirja nosile s seboj tudi drug material, kot so debla dreves, vejevje, melj in glina. Prihajalo je do zamašitev odvodnih lukenj in kanalov ter zato do večjih poplav in ojezeritev. V mirni jezerski vodi so se odlagali melj, glina in organski ostanki. Ko pa je voda pričela odtekati, so se tla zamočvirila in tako so nastale tanke, šoti podobne organogene plasti.

$\mathrm{Na}$ podlagi sinteze in interpretacije pridobljenih geoloških podatkov detajlnega geološkega kartiranja ter proučevanja in primerjave superpozicijskih odnosov smo prišli do sledečih ugotovitev:

Zaporedje usedlin kvartarne starosti na obravnavanem ozemlju sestavljajo vezani in nevezani klastični sedimenti, ki jih po litoloških značilnostih 
in po stratigrafski legi lahko razporedimo v pet litostratigrafskih enot. Te so: 1. karbonatni prod, 2. sive mastne gline, 3 . rjave ilovice, 4 . svetlosiva laporna glina in 5. močvirsko-aluvialne usedline.

1. litostratigrafska enota: $\mathrm{Na}$ območju Rašiške in Mišje doline ter Radenskega polja leži erozijsko in diskordantno na trdni kamninski podlagi dva do tri metre debela plast drobnega in srednje debelega, srednje sortiranega in srednje zaobljenega karbonatnega proda. Prod je bil v pleistocenu naplavljen $\mathrm{v}$ doline ter večje in manjše kotanje. Trdna podlaga kvartarnih usedlin je večinoma karbonatna, iz cordevolskega dolomita, zgornje triasnega dolomita in le redko iz spodnje ali srednje triasnega dolomita. Ponekod pa je trdna podlaga verjetno tudi iz klastičnih permokarbonskih in skitskih kamnin, ki sicer obrobljajo rašiško depresijo.

2. litostratigrafska enota: Bazalni prod prekriva 3.5 do $6 \mathrm{~m}$ debela plast različnih sivih mastnih glin, ki vsebujejo vložke melja, zelo drobnega peska, pogosto tudi več ali manj organskih ostankov in organskega detritusa. Te gline so uporabne za izdelavo zidne in strešne opeke. Mineralna sestava in kakovost glin se spreminjata tako $\mathrm{v}$ navpični kot v vodoravni smeri.

3. litostratigrafska enota: Sive mastne gline prehajajo navzgor brez presledka kontinuirano v rumenkasto, zelenkasto in rdečkasto rjavo ilovico, ki vsebuje leče sive gline ter pooglenele in bolj ali manj oksidirane organske ostanke. Plast rjavih ilovic je debela od 1 do $1.5 \mathrm{~m}$, njihova litološka sestava pa se hitro spreminja v vseh smereh. Ilovice vsebujejo tudi večje ali manjše število drobnih zrn različne mineralne sestave. Znaličnosti rjavih ilovic kažejo, da je njihov nastanek pogojen s spiranjem terra rosse in drugih preperin s pobočij ali s transportom površinskih vodnih tokov.

4. litostratigrafska enota. Navzgor sledi do 0.75 $\mathrm{m}$ debela plast svetlosive laporne gline, ki vsebuje številne pooglenele rastlinske ostanke. Po litološkem izgledu in mineralni sestavi je precej podobna holocenski barjanski laporni glini, t. i. "polžarici".

5. litostratigrafska enota. Kvartarno zaporedje usedlin Rašiške in Mišje doline ter Radenskega polja je pri vrhu zaključeno $\mathrm{z}$, do $0.75 \mathrm{~m}$ debelo enoto aluvijalno močvirskih usedlin, t.j. gline, melja in zelo drobnega peska, ki so bogate $\mathrm{z}$ organskim materialom. Včasih so v teh sedimentih tudi nezaobljeni drobci predvsem dolomita ali slabo zaobljen drobir mezozojskih in paleozojskih kamnin.

Debelina kvartarnih usedlin na obravnavanih kraških depresijah je bolj ali manj enotna in znaša od 7.5 do $10 \mathrm{~m}$. Za te usedline je značilno tudi to, da so zelo revne s fosilnimi ostaki, od katerih je še najbolj pogost pelod.

$S$ pelodno analizo vzorcev iz posameznih stratumov je bilo ugotovljeno, da so ti sedimenti skoraj izključno pleistocenske starosti, najverjetneje würmske. Doslej so bili sedimenti s holocensko vegetacijo ugotovljeni le v okolici Ponove vasi na Grosupeljskem polju ter na območju kraja Grosuplje.

\section{REFERENCES}

Buser, S. 1969: Osnovna geološka karta SFRJ 1:100000, list Ribnica. Zvezni geološki zavod, Beograd.

Buser, S. 1974: Tolmač lista Ribnica L 33-78. Osnovna geološka karta SFRJ 1:100000. Zvezni geološki zavod, Beograd, 60 pp.

Culiberg, M. 1991: Late Glacial Vegetation in Slovenia. Dela SAZU 29(10): 1-52. Ljubljana.

Dozet, S. 1982: Kočevsko ribniška ilovica. Rud.-met. zbornik 29(4): 269-280. Ljubljana.

Dozet, S. 1985: Geološke razmere na območju rudišča Pleše in v širši okolici. Rud.-met. zbornik 32 (1/2): 27-49. Ljubljana.

Dozet, S. \& Culiberg, M. 2005: Results of pollen and lithostratigraphic analysis of Quaternary deposits in Grosuplje Polje area. Hacquetia 4 (2): 201-207. Ljubljana.

Dunham, R. J. 1962: Classification of carbonate rocks according to depositional texture. In: HAM. W.E. (Ed.): Classification of carbonate rocks. AAPG, Mem. 1, 108-121. Tulsa.

Faegri, K. \& Iversen, J. 1992: Textbook of Pollen Analysis. $4^{\text {th }}$ Edition. John Wiley \& Sons. Chichester.

Folk, R. 1959: Practical petrographic classification of limestones. Bull. Am. Ass. Petrol. Geol. 43 (1): 2-38. Tulsa.

Gregorič, V. 1969: Nastanek tal na triasnih dolomitih. Geologija 12: 201-230. Ljubljana

Hrovat, A. 1953: Kraška ilovica, njene značilnosti in vpliv na zgradbe. Državna založba Slovenije, Ljubljana, 190 pp.

Kerčmar, D. 1961: Poročilo o geološkem kartiranju ozemlja med Grosupljem, Velikimi Laščami, 
Dobrepoljem in Višnjo goro. Geološki zavod Slovenije, Ljubljana, 60 pp.

Kossmat, F. 1905: Über die tektonische Stehlung der Leibacher Ebene. Verh. D. geol. R.-A. Wien: $71-85$.

Kossmat, F. 1906: Das Gebiet zwischen dem Karst und dem Zuge der Julishen Alpen. Jb.d. geol. R.-A: 259-276. Wien.

Lipold, M. V. 1858: Die Eisensteinführenden Diluvial-Lehme in Unter-Krain. Jb. Geol. R.-A. 9 (2): 246-257. Wien.

Lipold, M. V. \& Stache, G. 1859: Manuskriptna geološka karta Višnja gora - Cerknica 1:75 000, Wien.

Melik, A. 1955: Kraška polja Slovenije v pleistocenu. Razprave 4. razr. SAZU 7 (19): 51-54. Ljubljana.

Melik, A. 1959: Slovenija. Geografski opis. II. opis slovenskih pokrajin, 3. zvez., Posavska Slovenija. Slovenska matica, Ljubljana. 595 pp.

Meze, D. 1977: Prispevek k hidrogeologiji Radenskega polja. Geogr. vestnik 49: 157-164. Ljubljana.

Meze, D., Lovrenčak, F. \& Šercelj, A. 1981: Poplavna področja v Grosupeljski kotlini. Geogr. zbornik 20 (1980): 36-59. Ljubljana.

Pettijohn, F.J. 1975: Sedimentary rocks. Harper and Row, New York, 628 pp.

Radinja, D., Šifrer, M., Lovrenčak, F., Kolbezen, M. \& Natek, M. 1974: Geografsko proučevanje poplavnih področij v Sloveniji. Geogr. vestnik 46: 131-146. Ljubljana.

Rakovec, I. 1956a: Razvoj pleistocena na Slovenskem. Prvi jugosl. geol. kongres 1: 60-71. Ljubljana.

Rakovec, I. 1956b: Pregled tektonske zgradbe Slovenije. Prvi jugosl. geol. kongr.: 73-83. Ljubljana.

Šercelj, A. 1962: O kvartarni vegetaciji na Slovenskem. Geologija 7: 25-34. Ljubljana

Šercelj, A. 1966: Pelodne analize pleistocenskih in holocenskih sedimentov Ljubljanskega Barja. Razprave 4. razr. SAZU 9: 431-472. Ljubljana.

Šercelj, A. 1970: Würmska vegetacija in klima v Sloveniji. Razprave 4. razr. SAZU 7: 211-249. Ljubljana

Šercelj, A. \& Dozet, S. 1982: Prispevek k kronostratigrafiji, premoških, pliokvartarnih in kvartarnih usedlin v kočevski kotlini in okolici. Rud.met. zbornik 29 (2-3): 111-120. Ljubljana.

Šifrer, M. 1967: Kvartarni razvoj doline Rašice in Dobrega polja. Geogr. zbornik SAZU 10: 273305. Ljubljana.

Tancik, R. 1959: Pedološke značilnosti Ribniške in Kočevske doline. Geologija 5: 98-116. Ljubljana.

Žurga, P. J. 1938: Nekoliko iz geologije Dolenjske. V knjigi Dolenjska. Izdala in založila Tiskarna Merkur Ljubljana: 5-26. 